\title{
PROBLEM DALAM ASUMSI PSIKOLOGI BEHAVIORIS (SEBUAH TELAAH FILSAFAT ILMU)
}

\section{Lailiy Muthmainnah}

Fakultas Filsafat Universitas Gadjah Mada Yogyakarta,

Email : lailiy@ugm.ac.id

\section{Abstrak}

Behaviorisme sebagai sebuah aliran dalam psikologi menempati posisi yang sangat signifikan dalam beberapa dekade. Doktrin yang dikembangkan oleh behaviorisme dianggap mampu memberikan solusi bagi psikologi untuk mengatasi problem introspeksi sebagai sebuah metode yang digunakan dalam bidang studi psikologi. Adapun asumsi dasar dalam psikologi behavioris adalah (1) metode behavioris bersifat out-inside (dari luar ke dalam) sehingga fokus studi psikologi adalah pada perilaku dan bukan pada kondisi mental internal. Filosofi behavioris ini merupakan oposisi dari model berpikir cartesian yang inside-out. (2) Tujuan dari psikologi adalah prediksi perilaku. (3) Tubuh manusia bersifat mekanis yang secara kualitatif tidak jauh berbeda dengan hewan, hanya bersifat lebih kompleks saja, sehingga tidak ada perbedaan secara kualitatif antara perilaku manusia dan nonmanusia. Berdasarkan asumsi-asumsi tersebut di atas, maka persoalan mendasar yang kemudian muncul adalah sebagai berikut: (1) Diabaikan atau bahkan ditolaknya kesadaran sebagai bagian yang harus dipertimbangkan dalam perilaku manusia. (2) Penjelasan yang sangat mekanis ala behavioris hanya mampu menjelaskan perilaku manusia dalam term causa materialis, formalis, dan efficient, dengan mengabaikan kausa finalis yang lebih menekankan pada intensi tindakan. (3) Behaviorisme terlalu dogmatis dalam tujuannya untuk memprediksi perilaku. Terlepas dari persoalan-persoalan yang ada dalam asumsi psikologi behavioris, aliran ini tetap mampu memberikan kontribusi dalam menjelaskan perilaku masyarakat, mengingat pengaruh lingkungan (baik lingkungan fisik maupun sosial budaya dan ekonomi sebagai sumber stimulus yang efektif bagi perilaku individu.

Kata Kunci : behaviorisme psikologis, perilaku, mekanis, prediksi perilaku.

\section{Abstract}

Behaviorism as a mainstream in psychology occupies a very significant position in decades. Behaviorism developed a method that is able to overcome the shortcomings of introspection in psychology studies. There are three basic assumptions in behaviorist psychology : (1) The method of behaviorist is out-inside (from outside to inside) so that the focus of the study on psychology is behavior and not on the internal mental state. The method of behaviorist psychology is the opposition of the Cartesian model of thinking that is inside-out. (2) The purpose of psychology was the prediction of behavior. (3) The human body is mechanically qualitatively not much 
different with animals, just to be more complex, so that there is no qualitative difference between the behavior of humans and non-humans. Based on the above assumptions, the fundamental problem that then arises are follows: (1) Ignored or even rejection of consciousness as a part that should be considered in human behavior. (2) Explanation of a very mechanical style behaviorist only able to explain human behavior in terms of a materialist causa, formalist, and efficient, regardless of cause of finalists who put more emphasis on the intentions of the action. (3) Behaviorism too dogmatic in its aim to predict behavior. Regardless of the problems that exist in the assumptions behaviorist psychology, the flow is still able to contribute in explaining people's behavior, given the influence of the environment (both physical and social environment, cultural and economic) as a source of effective stimulus for the behavior of individuals.

Keywords: psychological behaviorism, behavior, mechanical, behavioral prediction.

\section{PENDAHULUAN}

Di dalam sebuah buku pengantar filsafat ilmu diceritakan tentang dua orang yang akan berlomba menembak. Satu di antaranya adalah orang yang memang jago menembak. Sedangkan yang satunya lagi adalah seorang petani biasa yang sama sekali tidak memiliki kemampuan menembak namun sedang dalam kondisi mabuk. Karena kondisinya yang sedang mabuk itulah maka dia berani mengajak bertanding seorang yang jago tembak tadi. Ketika keduanya bertanding untuk menembak, kemudian kepada yang lain ditanyakan tentang siapa yang akan menang, maka sebagian besar dari yang ditanya menjawab bahwa si penembak yang sudah terlatih yang akan menang dengan asumsi keahlian yang sudah dia miliki. Namun mungkin ada pula yang menjawab bahwa mungkin saja petani tersebut yang akan menang dengan asumsi dapat saja keberuntungan akan berpihak pada petani tersebut. Misalnya saja tiba-tiba pistol yang digunakan oleh si penembak jitu tadi tiba-tiba macet dan tidak dapat digunakan. Sehingga nasib mujur berada di tangan si petani. Namun berapa besar peluang hal itu untuk terjadi. Hal ini mengarahkan pada pemahaman bahwa sejak awal posisi yang dibangun dalam menjawab persoalan atas realitas adalah didasarkan pada asumsi yang bisa jadi akan berbeda satu sama lain (Suriasumantri, 1990:72). 
Pada cerita lain dikisahkan tentang beberapa orang ilmuwan yang meneliti tentang titik didih sebuah benda. Kemudian direbuslah air dalam sebuah teko besi yang kemudian di sampingnya berturut-turut diletakkan teko emas, teko perak, teko perunggu, dan teko alumunium. Kemudian lewat di hadapan para peneliti tersebut seseorang yang kemudian menanyakan aktivitas mereka. "Apa yang kalian lakukan?". Kemudian dijawab, “Kami sedang mengadakan percobaan". Lalu ditanyakan lagi, "Kenapa warna tidak kalian pertimbangkan dalam percobaan kalian?". Kemudian para peneliti itu menjawab, "Mana mungkin warna menentukan titik didih sebuah benda?". Dari jawaban tersebut dapat juga disimpulkan bahwa sejak awal para peneliti tersebut sudah memiliki asumsi bahwa tidak mungkin warna mempengaruhi titik didih benda (http://www.filsafatilmu.com/artikel).

Asumsi dalam sebuah ilmu sangatlah penting. Ada yang berpandangan bahwa idealnya sebuah ilmu harus bebas dari asumsi. Namun dalam kenyataannya justru asumsi pasti akan dibangun oleh peneliti sejak awal dalam proses riset yang mereka lakukan. Hal ini menarik karena jika asumsi akan selalu muncul dalam proses awal penelitian, maka hal-hal apa yang kemudian juga harus dipertimbangkan sebagai kelemahan atau mungkin kekurangan dari asumsi yang telah dibangun tersebut.

Pengertian asumsi dalam filsafat ilmu adalah anggapan dasar tentang realitas suatu objek yang menjadi pusat penelaahan atau fondasi dalam penyusunan pengetahuan ilmiah yang nantinya akan diperlukan dalam pengembangan ilmu. Asumsi yang dibangun sejak awal akan mengarahkan proses metodologi selanjutnya. Asumsi dasar dari suatu objek penelitian menjadi hal yang sangat penting dimiliki sebelum melakukan penelitian. Melalui asumsi yang dibangun oleh peneliti sejak awal maka hal apa yang ingin diteliti akan menjadi lebih jelas. Asumsi-asumsi yang dibangun oleh seorang peneliti akan memberikan batasan bagi ruang gerak peneliti sekaligus memberikan arah dan landasan bagi kegiatan penelitian 
yang dilakukan. Bidang ilmu apa pun pasti akan memiliki asumsi pokok dalam ilmunya, yang ini akan mempengaruhi setiap cara kerja atau metode riset yang digunakan dalam bidang ilmu yang bersangkutan. Asumsi tidak akan membawa pada kebenaran yang bersifat mutlak, namun demikian asumsi sebagai bagian penting dalam pencapaian sebuah ilmu akan menggiring para peneliti untuk berada pada ranah penafsiran yang bersifat probabilistik (Suriasumantri, 1990: 77).

Mengambil objek kajian tentang psikologi, problem tentang asumsi tersebut akan dibahas lebih rinci. Sebagaimana diperoleh dalam literatur pengantar psikologi, bahwa studi tentang jiwa dan badan sesungguhnya telah dimulai sejak masa Sokrates, Plato maupun Aristoteles, dalam A history of Psychology bahkan dikatakan bahwa kemunculan psikologi sebagai bagian dari filsafat telah ada semenjak Phytagoras menjelaskan konsep jiwa secara matematis. Psikologi baru berdiri sendiri sebagai sebuah ilmu dan terlepas dari filsafat pada sekitar tahun 1879, yang ditandai dengan didirikannya Laboratorium Psikologi di Leipzig Jerman dengan dipelopori oleh Wilhelm Wundt (1832-1920). Laboratorium ini merupakan Laboratorium pertama yang mempelajari tentang tingkah laku manusia (Benson dan Grove, 2001 : 25).

Adapun artikel ini memfokuskan diri pada behaviorisme. Behaviorisme atau psikologi perilaku atau sering juga disebut dengan psikologi "S-R" merupakan aliran psikologi yang berkembang dengan pesat, khususnya di Amerika. Aliran ini pertama kali diusung oleh John B. Watson (1878 -1958) dengan mengambil tesis bahwa studi psikologi harus fokus pada perilaku dan bukan pada proses introspeksi. Hal ini berbeda dengan studi psikologi yang dikembangkan dalam laboratorium Willem Wundt di Jerman yang lebih memfokuskan pada proses introspeksi. John B. Watson justru mengembangkan model psikologi yang tidak menggunakan introspeksi. Proses kesadaran bukanlah hal yang perlu untuk diselidiki, sebab yang penting adalah proses adaptasi, 
gerakan otot-otot, dan aktivitas kelenjar-kelenjar. Dengan fokus penelitian tersebut di atas maka psikologi di bawa ke arah yang lebih empiris.

Sebagai sebuah aliran dalam psikologi yang menekankan pada studi perilaku, maka behaviorisme secara keras menolak unsur-unsur kesadaran yang tidak nyata sebagai obyek studi dari psikologi, dan membatasi diri hanya pada studi tentang perilaku yang nyata. Behaviorisme tidak setuju dengan penguraian jiwa ke dalam elemen seperti yang dipercayai oleh strukturalisme. Behaviorisme melangkah lebih jauh dari fungsionalisme yang masih mengakui adanya jiwa dan masih memfokuskan diri pada prosesproses mental. Sebagaimana John Locke dengan tabularasa-nya, behaviorisme juga menganggap bahwa lingkungan merupakan faktor utama yang akan menentukan perilaku manusia, jiwa hanya bersifat pasif. Perilaku merupakan hal yang muncul dari proses belajar manusia. Dalam konteks ini maka perilaku dapat diprediksi karena perilaku manusia sesungguhnya merupakan bentuk reaksi mekanis dari proses-proses biologis semata. Berdasarkan latar belakang masalah tersebut di atas, maka poin-poin pertanyaan yang dapat diajukan adalah: Apa asumsi yang dibangun oleh psikologi behavioris? Apa persoalan mendasar dari asumsi yang dibangun oleh psikologi behavioris? Serta adakah relevansi pemikiran behaviorisme ini dalam konteks perilaku kehidupan masyarakat modern?

\section{MUNCULNYA BEHAVIORISME SEBAGAI MAINSTREAM DALAM PSIKOLOGI}

Secara etimologi psikologi berasal dari kata psyche yang berarti pikiran, jiwa, atau ruh serta logos yang berarti pengetahuan, wacana, ataupun kajian. Berdasarkan asal kata tersebut, maka psikologi kemudian didefinisikan sebagai kajian tentang pikiran. Kemunculan psikologi sebagai sebuah disiplin ilmu yang terpisah dari filsafat dengan sifat yang empiris terjadi pada tahun 1879. Hal 
ini ditandai dengan didirikannya laboratorium psikologi pertama di Universitas Leipzig Jerman oleh Wilhelm Wundt (1832-1920). Dengan munculnya behaviorisme pada tahun 1920, pemisahan antara psikologi dan filsafat menjadi lebih ideologis, yaitu dengan dijadikannya psikologi menjadi lebih profesional. Beberapa tokoh yang cukup vokal terkait upaya pemisahan ini antara lain yaitu J.B. Watson, Weiss, Hunter, Lashley yang berpandangan bahwa psikologi harus menjadi sesuatu yang radikal dan berbeda dari filosofi. Utamanya yaitu dalam pokok persoalan "mind (pikiran) vs perilaku"; dan metode "observasi empiris vs introspeksi dan spekulasi terjaga". Dalam sudut pandang ini, psikologi menjadi ilmu empiris, ilmu alam yang menyelidiki perilaku organisme murni secara empiris, terobservasi, dan menggunakan sarana eksperimental. Filsafat sebagai kebalikannya, terdiri atas kajian spekulatif tentang entitas yang tidak terobservasi yang sering kali didasarkan pada intuisi maupun introspeksi, dan klaim terhadap beberapa kepastian yang bersifat transenden ataupun transendental. Di sini terjadi pertempuran antara "empirisme vs rasionalisme", "fakta vs teori", fakta vs norma, dll. Oleh karena itu, meskipun filsafat memiliki sesuatu yang dapat diperlukan oleh bidang psikologi, namun kebanyakan dari individu-individu semisalnya JB. Watson berpikir bahwa psikologi tidak dapat belajar apa pun dari filsafat, sehingga filsafat harus dihindari (O'Dohonue, 1996: xiii).

Meskipun demikian, pada tahap awal berpisahnya psikologi dari filsafat, fokus penelitian atau kajian pada laboratorium yang didirikan oleh Wilhelm Wundt adalah menyelidiki "aktivitas pikiran" melalui proses introspeksi. Introspeksi yang dimaksudkan di sini adalah mengamati dan menganalisis pikiran sadar menjadi elemen-elemen dasar serta menganalisis persepsi menjadi sensasisensasi konstituennya. Upaya untuk mengidentifikasi struktur pikiran inilah yang kemudian disebut dengan strukturalisme (Gross, 2012: 4-5).

Proses identifikasi atas struktur pikiran tersebut di atas dilakukan oleh Wundt secara terkontrol, yaitu dengan menggunakan 
stimulus yang sama, instruksi verbal yang sama, ataupun lingkungan yang sama terhadap partisipan. Pada tahap inilah terjadi proses terpisahnya psikologi dari induknya, yaitu filsafat. Psikologi sebagai sebuah disiplin ilmu baru lebih berfokus pada pengukuran dan kontrol sebagai metode dasar dalam investigasi ilmiah pada ranah kajian proses-proses mental, berbeda dengan apa yang didiskusikan oleh para filsuf yang juga banyak mendiskusikan tentang pikiran.

Setelah berhasil memisahkan diri dari filsafat dan membentuk disiplin ilmu baru, psikologi mengalami banyak perkembangan yang ditandai dengan munculnya berbagai aliran/teori dalam psikologi. Jika pada kemunculan psikologi sebagai ilmu, model strukturalisme yang dipelopori oleh Wundt menempati posisi yang cukup bergengsi, namun kemudian muncul tantangan dari aliran fungsionalisme yang dipelopori oleh psikolog Amerika Serikat William James (1842-1910).

William James adalah seorang dosen di Harvard University untuk mata kuliah anatomi dan fisiologi, namun dimulai pada tahun 1875 dia mulai mengembangkan relasi antara fisiologi dan psikologi. Begitu kuat minatnya pada bidang ini sampai dia meninggalkan bidang anatomi dan fisiologi yang telah lama digelutinya dan beralih pada psikologi murni dengan mendirikan laboratorium kecil untuk mendukung studi psikologinya tersebut.

Fungsionalisme yang diusung oleh W. James mengkritik konsep Wundt yang terlalu mendalam tentang struktur dan elemen jiwa. Menurut William James, sebagai pelopor fungsionalisme, psikologi harusnya lebih berfokus pada fungsi jiwa. Hal ini dipengaruhi oleh cara berpikir ala Amerika Serikat yang serba pragmatis, sehingga jiwa dalam sudut pandang aliran ini adalah berfungsi sebagai alat manusia untuk menyesuaikan diri dengan lingkungan (Sarwono, 2009: 26-27).

Selain fungsionalisme, aliran selanjutnya yang juga berkembang di Amerika Serikat adalah behaviorisme. Aliran ini dipelopori oleh John B. Watson (1878 - 1958). Langkah awal yang 
dilakukan oleh Watson adalah memutuskan hubungan antara psikologi dengan fisiologi dan untuk kemudian memperkuat pertaliannya dengan biologi. Jika pada Wundt dan William James masih berkisar pada problem kesadaran sebagai psikologi murni, maka Watson yang memang sedang melakukan riset terhadap binatang-binatang menjadi semakin kritis terkait penggunaan metode introspeksi. Behaviorisme secara khusus mempersoalkan validitas dari metode introspeksi yang digunakan oleh Wundt dalam mengidentifikasi struktur pikiran. Hal ini disebabkan karena introspeksi tidak akan pernah dapat dibuktikan ataupun dibantah. Sebagai contoh adalah ketika ada dua orang yang menghasilkan dua penjelasan introspektif yang berbeda, maka sulit untuk menentukan mana yang secara objektif benar. Hal ini disebabkan karena secara objektif pihak lain akan mengalami kesulitan untuk memeriksa keakuratan hasil introspeksi tersebut. Karena sejatinya penjelasan introspeksi bersifat sangat subjektif, dan hanya individu itu sendiri yang dapat memahami proses mentalnya (Gross, 2012: 4) Lebih lanjut Watson memberikan konsep baru, bahwa seharusnya psikologi lebih berfokus pada upaya untuk mempelajari perilaku, sebab hanya perilaku-lah yang dapat diobservasi ataupun diukur oleh orang lain. Oleh karena itu proses introspeksi dalam psikologi haruslah dihilangkan.

Pada karya John B. Watson yang berjudul "Psychology as The Behaviorist Views It" atau yang lebih dikenal dengan manifesto behaviorist yang dipublikasikannya di tahun 1913, dinyatakan bahwa behaviorisme lah yang membawa psikologi menjadi benarbenar ilmiah, karena mampu merepresentasikan sebuah pendekatan empiris yang taat asas.

"Psikologi seperti yang dilihat oleh behavioris adalah sebuah ilmu pengetahuan alam objektif murni. Tujuan teoritiknya adalah prediksi dan kontrol perilaku. Introspeksi tidak menjadi bagian esensial metodenya; nilai ilmiah datanya juga tidak tergantung pada kesiapannya untuk diinterpretasi dalam kaitannya dengan kesadaran. Behavioris tidak mengenal 
garis pemisah antara manusiawi dan kebrutalan. Perilaku seorang manusia hanya sebagian dari total skema investigasi behavioris"(Watson dalam Gross, 2012: 48).

Tiga kunci utama yang dapat ditemukan dalam manifesto behavioris adalah sebagai berikut :

1. Psikologi harus murni objektif, mengesampingkan semua data subjektif atau interpretasi dalam kaitannya dengan pengalaman sadar (psychology as the science of behavior);

2. Tujuan psikologi adalah untuk memprediksi dan mengontrol perilaku (hal ini sebagai lawan dari apa yang sudah dilakukan oleh Wundt, yaitu mendeskripsikan dan menjelaskan keadaankeadaan mental sadar). Konsep ini nantinya akan dikembangkan oleh BF. Skinner dengan model behaviorisme radikal);

3. Tidak ada perbedaan secara kualitatif (fundamental) antara perilaku manusia dan non-manusia. Mengacu pada yang diteorisasikan oleh Darwin, bahwa manusia berevolusi dari spesies yang lebih sederhana, maka perilaku manusia dapat disimpulkan sebagai bentuk perilaku yang lebih kompleks dari spesies-spesies yang lain. Artinya, tidak ada perbedaan secara kualitatif antara hewan dan manusia, yang berbeda hanya pada tataran kuantitatif (derajatnya). Konsekuensinya karena pada saat itu Watson sedang melakukan penelitian terhadap beberapa hewan (tikus, kucing, anjing, dan merpati), maka data yang diperoleh dari hewan tersebut akan menjadi data utama. Hal ini ditegaskan oleh Watson karena psikologi sekarang ini bukanlah bicara tentang "kesadaran" melainkan "perilaku". Oleh karena itu hewan yang lingkungannya lebih mudah untuk dikontrol ataupun dikondisikan dianggap sah untuk digunakan sebagai sumber data atau subjek eksperimen menggantikan manusia (Watson dalam Gross, 2012:48).

Pemikiran behavioris Watson kemudian dikembangkan lagi secara lebih radikal oleh B.F. Skinner yang berfokus pada upaya untuk melakukan prediksi perilaku. Ciri khas yang dapat ditemukan 
dalam pemikiran Skinner adalah konsistensi dalam menentang setiap upaya untuk mengisi kekosongan atau jurang antara peristiwa-peristiwa yang teramati dengan variabel-variabel yang disimpulkan atau dihipotesakan. Tujuan Skinner adalah mengumpulkan "hukum-hukum tingkah laku" tanpa dengan menggunakan penjelasan yang bersifat khayalan (mental, internal). Untuk sampai pada hukum-hukum tingkah laku tersebut, Skinner menggunakan eksperimentasi yang eksak dan data yang terkontrol (Supratiknya, 1993: 315-316).

Eksperimen Skinner dijalankan secara induktif dengan menggunakan subjek individual. Skinner tidak sekedar berhenti pada penguatan yang terjadi setelah diberikannya stimulus, melainkan lebih fokus pada upaya untuk menemukan hubunganhubungan yang sangat teratur antara pola-pola penguatan tertentu dan bentuk respon yang muncul. Skinner fokus pada respon-respon yang dilakukan dan bukan respon yang ditimbulkan, sehingga tekanannya adalah pada operan-operan bukan respondenresponden. Skinner meyakini bahwa prinsip-prinsip umum yang sama tentang tingkah laku akan dapat diungkap, tidak peduli organisme, stimulus, respon, ataupun pemerkuat seperti apa pun yang dipilih oleh periset untuk diteliti. Hasil riset merpati di laboratorium misalnya tetap dapat digunakan sebagai sebuah paradigma yang kemudian dapat diekstrapolasikan dan diperluas pada organisme yang lain, termasuk manusia (Supratiknya, 1993: 317).

\section{ASUMSI-ASUMSI DALAM PSIKOLOGI BEHAVIORIS}

Sebagaimana telah dijelaskan di atas, bahwa perkembangan behaviorisme psikologis sangat dipengaruhi oleh adanya manifesto John Watson pada tahun 1913, "Psychology as the behaviorist views it" (Watson, 1913) dan gerakan ini memegang kekuasaan, khususnya di Amerika Utara sekitar 5 dekade. John B. Watson telah mentransformasikan ranah kajian psikologi dari pikiran ke perilaku, inilah yang kemudian disebut dengan methodological behaviorism. Apa 
yang digagas oleh Watson pada "manifestonya" nyaris diterima oleh begitu saja oleh para psikolog. Mereka berkeyakinan akan pentingnya metode empiris, melalui eksperimentasi untuk memperoleh data tentang manusia maupun non manusia yang kemudian dapat dikuantifikasi dan dianalisis secara statistik. Pada tataran behaviorisme metodologis seperti yang dikembangkan oleh Watson tersebut, eksistensi pikiran dan perasaan masih diterima meskipun hal ini tidak mereka tangani karena sifatnya yang internal sehingga tidak dapat dikonfirmasi oleh pihak lain.

Dalam perkembangan behaviorisme lebih lanjut, muncullah model behaviorisme radikal yang dikembangkan oleh B.F. Skinner. Pada pemikiran behaviorisme radikal lebih ditegaskan lagi bahwa perasaan, sensasi, dan juga kejadian pribadi tidak dapat digunakan untuk menjelaskan perilaku, tetapi akan dijelaskan dalam analisis perilaku. Apabila pada behaviorisme metodologis diusulkan untuk mengabaikan keadaan batin ini (karena tidak dapat diakses), namun pada behaviorisme radikal Skinner, hal-hal tersebut ditolak sebagai variabel-variabel yang dapat menjelaskan perilaku (dianggap tidak relevan), dan berpendapat bahwa apa yang dimaksudkan tadi sesungguhnya dapat diterjemahkan dalam bahasa teori "reinforcement"(Skinner dalam Gross, 2012: 19).

Meskipun ada sedikit perbedaan di antara tokoh-tokoh behavioris tersebut di atas namun secara umum asumsi utama yang digunakan oleh behaviorisme psikologis adalah psikolog harus membatasi diri untuk menggambarkan hubungan antara fitur eksternal yang diamati dari organisme dengan kondisi internal yang tersembunyi dari organisme. Ada dua alasan penting mengapa behaviorisme psikologis ingin membebaskan diri dari pembicaraan tentang kondisi mental. Alasan pertama yaitu secara epistemologis behaviorisme psikologis tertarik dengan ajaran positivis sebagai keharusan bagi sebuah teori ilmiah. Pada sudut pandang positivis, teori-teori ilmiah harus dapat diobservasi atau secara jelas dapat diamati oleh publik. Sementara itu kondisi mental adalah sesuatu hal yang berada di dalam (inner), sehingga tidak dapat diamati oleh 
pihak lain/publik. Kondisi ini mengakibatkan tidak adanya mekanisme yang tepat untuk mengobservasi kondisi mental, sehingga tidak dapat diketahui proses mental apa yang sebenarnya terjadi.

Alasan kedua bagi behaviorisme psikologis adalah banyak cara yang lebih menarik dan lebih mendalam untuk menjelaskan, yang hal ini membawa behaviorisme psikologis pada akhirnya jatuh sebagai sebuah program riset. Behaviorisme psikologis melihat bahwa tugas sulit dari psikologi adalah memformulasi hukum, seperti halnya menggeneralisasikan perilaku. Dalam upaya mengejar hal ini, mereka melihat bahwa meletakkan kondisi mental sebagai hal yang terletak di tengah-tengah antara input lingkungan dan perilaku yang tampak sebagai penjelasan yang berlebih-lebihan. Argumentasinya adalah, jika diasumsikan ada hubungan yang sah antara stimulus lingkungan dan kondisi mental yang di dalam, serta hubungan yang sah antara kondisi mental "di dalam" dengan produksi perilaku, maka dapat dikatakan juga sebagai sah hubungan antara stimulus lingkungan dan perilaku dengan tanpa memperhatikan kondisi mental yang ada di dalam sebagai mediator. Meletakkan kondisi mental merupakan pekerjaan tambahan, mengingat hal ini tidak terjangkau secara epistemis, sehingga psikologi lebih baik mengabaikan hal ini. BF. Skinner meletakkan beberapa poin secara ringkas:

"Jika semua hubungan adalah sah, seharusnya tidak ada yang hilang dengan pengabaian hubungan terhadap hal-hal yang non fisik (mental). Oleh karena itu, jika kita tahu bahwa seorang anak tidak makan untuk waktu yang cukup lama, dan jika kita tahu bahwa oleh karena itu dia akan merasa lapar, dan karena dia merasa lapar maka dia akan makan, maka kita tahu bahwa jika dia tidak makan untuk waktu yang cukup lama, maka dia akan makan“.

Di antara hal yang paling signifikan dari prestasi behavioris adalah perumusan sejumlah aturan penting pembelajaran. Contoh aturan tersebut adalah Law of Effect dari Thorndike, yang diberikan oleh psikolog behavioris Edward Thorndike, yang mengatakan 
bahwa jika suatu organisme melakukan beberapa perilaku $\mathrm{X}$ dan $\mathrm{X}$ diikuti oleh penguatan, maka probabilitas dari organisme melakukan X lagi di masa depan akan meningkat (Thorndike, 1911). Behavioris memformalkan banyak aturan pembelajaran tersebut dan menghasilkan generalisasi yang berhasil menunjukkan bagaimana aturan-aturan pembelajaran berhasil memprediksi perilaku hewan, setidaknya dalam konteks eksperimental tertentu.

Dengan kata lain behaviorisme sangat menekankan peran faktor lingkungan dalam memengaruhi perilaku, sehingga nyaris mengabaikan faktor-faktor hereditas. Pembelajaran akan terjadi melalui proses conditioning, baik classical (seperti yang terjadi pada Pavlov ataupun responden yang menjadi dasar behaviorisme Watson) maupun operant conditioning (seperti yang terjadi pada model behaviorisme radikal ala Skinner). Perbedaan dari dua model ini hanyalah pada cara mereka mendefinisikan hubungan stimulus dan respons. Jika pada classical conditioning dilihat bahwa stimulus akan memicu respons secara otomatis dan dapat diprediksi (inilah yang disebut dengan psikologi S-R). Hal ini berbeda dengan model operant conditioning (ABC operant condioning) Skinner, bahwa perilaku akan ditentukan oleh konsekuensinya. Dari penjelasan tersebut di atas dapat disimpulkan bahwa kedua tipologi behaviorisme tersebut di atas, sesungguhnya sama dalam memahami asumsi tentang manusia yaitu sama-sama mekanis dan asumsi tentang manusia yang sangat mekanis ini juga yang kemudian digunakan untuk menjelaskan prediksi perilaku.

\section{PROBLEM-PROBLEM DALAM ASUMSI PSIKOLOGI BEHAVIORIS}

Berdasarkan asumsi yang dibangun oleh behaviorisme tersebut di atas, dapat ditemukan beberapa persoalan mendasar sebagai berikut (International Encyclopedia of Social Science, 2008: 280281):

Problem pertama adalah behaviorisme mengabaikan atau bahkan menolak kesadaran. Sebagaimana yang telah dijelaskan pada 
bagian sebelumnya, behaviorisme sangat fokus pada perilaku eksternal dan mengabaikan kondisi-kondisi mental (internal) atas kesadaran. Padahal kesadaran adalah hal yang membuat manusia memahami apa yang dilakukan dan dirasakan, perasaan, tindakan, sensasi, ataupun hal-hal lainnya. Behaviorisme metodologis mengabaikan kondisi mental internal (kesadaran) ini dengan alasan bahwa kondisi tersebut tidak dapat diakses oleh pihak lain. Hal ini dikarenakan secara epistemologis behaviorisme berasumsi jika kepercayaan dan keinginan dipahami sebagai hal yang tersembunyi pada keadaan batin seseorang, maka sulit atau bahkan tidak mungkin pihak lain untuk dapat mengakses kondisi pada orang lain, sehingga potensi skeptisisme tentang pikiran orang lain akan terjadi. Oleh karena itu, behaviorisme lebih memahami kondisi mental sebagai disposisi untuk berperilaku dalam cara tertentu. Dengan jalan yang seperti behaviorisme asumsikan maka pengetahuan tentang kondisi-kondisi mental dari pihak lain akan dapat dijelaskan, serta skeptisisme tentang pikiran orang lain dapat di hilangkan (Mason, hal 4). Tetapi kembali hal ini membawa persoalan besar yang berkaitan dengan kesadaran. Behaviorisme akan mengalami kesulitan yang sangat besar ketika harus menjelaskan kondisi-kondisi mental internal, semisal perasaan. Contohnya ketika seseorang merasakan sakit yang sangat mendalam, mencicipi dan merasakan sesuatu hal, coklat misalnya, atau bagaimana misalnya seorang behavioris akan menjelaskan bayangan atau lamunan seseorang.

Problem kedua adalah model penjelasan yang sangat mekanis ternyata tidak mencukupi untuk menjelaskan perilaku manusia. Penjelasan yang digunakan oleh kalangan behavioris dengan model hubungan stimulus-respon dipandang sangat tidak memadai untuk menjelaskan perilaku manusia. Model stimulus respon ini mengandaikan bahwa selalu ada kesesuaian antara kondisi mental internal yang terjadi dengan stimulus eksternal dan respon eksternal. Padahal kondisi mental internal mungkin merupakan respon bersama yang muncul dengan umpan balik 
sensori. Hal ini berarti bahwa cara pandang behavioris dalam melihat perilaku manusia sehari-hari sebagai sangat mekanis dan merupakan respon fisik semata, sangat tidak memadai. Cara pandang yang sangat mekanis ini tidak akan mampu menjelaskan beragam konsepsi perilaku manusia, seperti misalnya melambai, memberi sinyal, bercumbu, memberikan gerak sebagai berisyarat tertentu, dll. Hal ini disebabkan karena tindakan tidaklah bersifat mekanistik melainkan lebih bersifat intensional, teleologis, sesuai dengan aturan hukum, mengikuti kaidah norma sosial, dan lain-lain yang ini semua sangat berbeda dengan penjelasan yang diberikan oleh behaviorisme. Bahkan ada dari perilaku manusia yang terkadang memiliki makna yang lebih bersifat "dramaturgi". Sebagai contoh adalah kondisi mental atas rasa sakit yang dialami pada diri seseorang. Hal ini terkadang tidaklah selalu ekuivalen dengan seperangkat perilaku yang dapat dilihat oleh pihak lain, karena ada kemungkinan bagi seseorang yang sakit tersebut untuk menyembunyikan. Misalnya, ada seseorang yang sesungguhnya benar-benar merasakan sakit namun karena takut dikatakan "tidak macho", maka dia menahan rasa sakitnya dan berpura-pura tidak sakit. Hal yang semacam ini tentu tidak dapat digunakan untuk menjelaskan perilaku secara objektif, seperti yang dikehendaki oleh behaviorisme.

Problem ketiga adalah tujuan behaviorisme yaitu untuk memprediksi perilaku dinilai sangat dogmatis. Kaum behavioris yakin bahwa proses dan kondisi mental internal tidak diperlukan untuk menjelaskan perilaku, dalam hal ini prediksi perilaku. Pada tahap awal sebagaimana telah dijelaskan dalam problem pertama keadaan mental internal akan diabaikan, atau bahkan dalam tingkatan behaviorisme radikal akan ditolak keberadaannya. Hal ini disebabkan karena proses yang terjadi dalam kondisi mental internal dianggap tidak layak untuk digunakan sebagai bahan kajian ilmiah karena tidak dapat diobservasi (efek model positivisme). Padahal pertanyaan tentang apa yang menarik ataukah yang tidak menarik, layak ataukah tidak dalam sebuah studi ilmiah tidaklah dapat diatur 
dengan cara seperti ini. Pada beberapa dekade terakhir, psikolog dan ahli saraf bahkan telah sukses mengidentifikasi saraf dan mekanisme sinaptik yang mendasari beberapa aturan pembelajaran yang awalnya dirumuskan oleh para psikolog behavioris seperti Pavlov, Thorndike, Skinner. Tidak hanya melakukan identifikasi keteraturan perilaku namun lebih dari itu juga mengkaji secara spesifik kondisi internal yang memediasi keteraturan perilaku tersebut.

Problem keempat adalah penjelasan behavioris terkait perilaku ini ternyata tidak dapat digunakan untuk menjelaskan perilaku kebahasaan manusia. Penjelasan behavioris mungkin memang cocok untuk diterapkan pada hewan yang relatif sederhana dengan proses conditioning untuk konteks eksperimental tertentu yang sangat terbatas. Sebagai contoh adalah merpati yang belajar mematuk tuas untuk mendapatkan makanan pelet. Tapi sebenarnya dalam konteks ekologi, jauh lebih realistis gagasan tentang perilaku hewan tersebut dijelaskan dengan Law of Effect-Thordike. Sementara itu perilaku manusia sesungguhnya sangat kompleks. Termasuk di dalam hal ini adalah perilaku kebahasaan, yaitu kemampuan manusia untuk memproduksi dan memahami bahasa yang sangat kompleks, sehingga penjelasan behavioris dengan model stimulusrespon akan sangat tidak masuk akal.

Selain itu problem yang juga dihadapi oleh behavioris adalah menjelaskan adanya hubungan langsung antara kondisi mental dan disposisi yang muncul dalam perilaku tertentu. Hal ini disebabkan karena tampaknya hubungan antara kondisi mental dan perilaku selalu dimediasi oleh sejumlah faktor, terutama oleh kondisi-kondisi mental lainnya. Sebagai contoh kasus misalnya Paulus sakit kepala. Kaum behaviorisme mengatakan bahwa kondisi Paulus yang sakit kepala dapat dilihat dari sejumlah perilaku yang Paulus lakukan, misalnya mengambil aspirin. Namun mengapa Paulus mengambil aspirin atau mungkin juga sebaliknya tidak mengambil aspirin, hal ini tampaknya akan berkaitan dengan kondisi mental yang lain dari Paulus, termasuk dalam hal ini keyakinan orang lain, keinginan, preferensi, dll. Sebagai contoh 
misalnya Paulus meyakini bahwa penggunaan aspirin akan mengganggu asam lambungnya, atau misalnya Paulus tidak menyukai obat-obatan dan lebih memilih solusi alami seperti pijat, maka Paulus tidak akan menggunakan aspirin (Mason, hal 5). Berdasarkan kasus tersebut di atas dapat diambil evaluasi bagi behaviorisme bahwa keyakinan, keinginan, dan kondisi mental yang lain memang dapat dipahami dalam produksi perilaku. Namun keterkaitan penyebab sistematik atas kondisi mental di dalam produksi perilaku membuat mungkin untuk memberikan kepada masing-masing kondisi mental dalam dirinya sendiri percabangan perilaku yang unik di luar yang dibayangkan oleh behaviorisme (Mason, hal 5).

\section{ANALISIS KRITIS ATAS PROBLEM-PROBLEM ASUMSI DALAM PSIKOLOGI BEHAVIORIS}

Dari paparan tersebut di atas dapat diketahui bahwa pemikiran behaviorisme sangat bertolak belakang dengan paradigma Cartesian. Filosofi dalam model Cartesian sering disebut dengan filsafat inside-out, yaitu apa yang dipersepsi oleh manusia bukanlah karena ada benda-benda di luar diri manusia, melainkan karena adanya ide yang dimiliki manusia yang muncul dalam diri (Cogito). Pandangan behavioris sangat bertentangan dengan konsep Cartesian tersebut, karena dalam model behaviorisme justru sebaliknya, bahwa pengetahuan (termasuk juga dalam hal ini adalah perilaku) dapat diperoleh manusia karena adanya interaksi dengan faktor luar atau lingkungan, sehingga filosofinya lebih ke arah dari luar ke dalam, bukan sebaliknya.

Implikasi dari model berpikir ala Cartesian adalah diterimanya pikiran sebagai satu-satunya hal yang dapat diketahui dengan pasti. Konsep dualisme Descartes juga berkonsekuensi pada dipisahkannya cogitan dan extensa, sehingga tubuh pada akhirnya diterima sebagai hal yang bersifat mekanis. Tubuh tersusun atas materi, oleh karenanya akan memiliki karakteristik sebagaimana yang dimiliki oleh materi secara umum, yakni menempati ruang dan 
mampu bergerak. Karena tubuh adalah materi maka penjelasan atas gerak tubuh dapat dijelaskan secara mekanis seperti halnya bekerjanya sebuah mesin. Oleh karena tubuh hanyalah bersifat mekanis, maka untuk memahami proses apa yang terjadi dalam tubuh manusia, maka dapat dilakukan melalui proses introspeksi, memahami ataupun merefleksikan pikiran itu sendiri.

Karena menggunakan proses introspeksi, maka muncul persoalan validitas. Metode introspeksi tersebut akan membawa konsekuensi pada munculnya solipsisme. Hal ini disebabkan karena proses introspeksi hanya dapat dijalankan oleh individu yang bersangkutan, sehingga pihak lain tidak akan pernah tahu apa yang ada dalam pikiran orang lain. Akibatnya, hanya pengalaman diri sendiri yang dapat diterima sebagai fakta, sedangkan yang lain tidak diterima. Kondisi ini mengakibatkan persoalan bagi psikologi yang menghendaki masuk menjadi sebuah disiplin ilmu empirik. Persoalan inilah yang kemudian dijawab oleh behaviorisme dengan upayanya untuk lebih mengempiriskan psikologi.

Asumsi behaviorisme atas manusia yang mekanis, membawa konsekuensi pada penjelasannya yang mengesampingkan penyebab final (final cause) dalam penjelasan perilaku. Kondisi ini sesungguhnya merupakan sebuah akibat dari kebangkitan sains Newtonian, di mana model analisis ala Aristotelian, yaitu material cause (penyebab kejadian), efficient cause (penyebab aksi), formal cause (penyebab bentuk), dan final cause (penyebab tujuan) tidak semuanya digunakan. Perkembangan sains Newtonian telah menghilangkan penyebab final dalam penjelasan alam semesta secara luas, yang dalam konteks behaviorisme psikologis adalah dihilangkannya penyebab tujuan dalam penjelasan perilaku. Hal ini dilakukan dengan alasan bahwa ketika ilmuwan terlalu fokus pada penyebab final, maka mereka akan mengabaikan penyebab material dan efisien. Padahal dalam dominasi sains Newtonian, ilmuwan harus lebih fokus pada pertanyaan "bagaimana" daripada "mengapa", sehingga asumsi mekanis atas diri manusia menjadi memperoleh 
tempat yang akan dijalankan melalui proses eksplanasi nantinya (Rychlak, 1996:150).

Eksplanasi yang berasal dari kata ex dan planare, berarti membuat datar atau sederajat. Maksudnya adalah, ketika eksplanasi dilakukan maka hal tersebut harus dilakukan dengan menggunakan kerangka dasar yang sama. Dalam konteks psikologi setidaknya ada empat kerangka dasar yang seringkali digunakan dalam eksplanasi, yaitu: physikos, bios, logos, dan socius. Masing-masing konsep tersebut di atas memiliki ranah yang berbeda. Physikos adalah hal yang bersifat fisik, non-organis. Bios dibedakan dengan physikos karena bios lebih mengacu pada organisme yang hidup. Socius bekerja didasarkan pada sebuah proses seperti identitas kelas sosial yang membungkus perilaku individu dalam pola-pola tertentu. Konsep socius lebih menekankan pada perilaku manusia dalam masyarakat. Sedangkan logos sebagai lawan dari bios, sebagaimana analogi mind and body, lebih mengarah pada gagasan, pemikiran, atau penalaran (Rychlak, 1996:151).

Persoalan dari empat konsep tersebut di atas muncul ketika sebuah basis tertentu kemudian dijadikan sebagai faktor determinan bagi basis yang lain. Sebagai contoh adalah konsepsi logos yang didasarkan pada penyebab final. Dalam konteks ini perilaku seseorang sangat ditentukan oleh maksud dan tujuan dari perilaku tersebut sejak awal, sehingga penjelasan tentang perilaku akan mengarah pada pemahaman tentang intensi dari perilaku yang dimaksudkan. Oleh karena itu, akan sangat tidak relevan ketika penjelasan perilaku sekedar diletakkan pada penyebab efisien (prinsip aksi), yang hal ini sebenarnya juga digunakan pada penjelasan dasar physikos dan bios.

\section{KONTRIBUSI BEHAVIORISME DALAM PENJELASAN PERILAKU MASYARAKAT MODERN}

Terlepas dari berbagai problem yang muncul dalam asumsi keilmuannya, behaviorisme tetap memiliki pengaruhnya yang signifikan. Pada konteks kehidupan masyarakat modern 
sesungguhnya banyak hal yang dapat diambil dari teori behaviorisme ini, terutama dalam hal penjelasan perilaku. Dalam paparan di atas telah dijelaskan bahwa pada sudut pandang behaviorisme, perilaku seseorang akan sangat dipengaruhi oleh faktor eksternalnya, sehingga faktor kesadaran menjadi hal yang tidak disentuh oleh behaviorisme dalam penjelasannya. Artinya tindakan seseorang murni sebagai respon dari stimulus eksternal yang diperoleh, baik secara spontan maupun melalui pembelajaran (clasical and operant conditioning). Terlepas dari kelemahan dari gagasan tentang peran utama faktor eksternal dalam membentuk perilaku karena mengabaikan kesadaran manusia namun yang perlu dicatat adalah proses pembelajaran akan tetap dilakukan individu setelah memperoleh stimulus dari lingkungan (faktor eksternal).

Terkait dengan proses pembelajaran tersebut, maka yang harus diperhatikan dengan cermat adalah bentuk stimulus seperti apa yang diberikan oleh faktor eksternal kepada individu. Apakah stimulus lingkungan tersebut termasuk stimulus yang positif atau negatif (terkait dengan term-term moral misalnya). Sebagai contoh kasus adalah posisi media sosial di era global. Dengan semakin canggihnya perkembangan teknologi informasi di era sekarang, maka berbagai hal dapat diakses dengan sangat mudah dalam waktu yang sangat singkat. Berbagai situs bertebaran dan semuanya menyajikan beragam informasi, baik yang layak maupun yang tidak layak untuk dinikmati oleh penikmatnya. Jika apa yang diteorisasikan oleh behaviorisme benar, maka apa yang ada di dunia teknologi informasi sekarang ini semuanya memiliki kapasitas yang sangat kuat sebagai stimulan. Berbagai informasi dari dunia maya tersebut merupakan stimulan yang sangat kuat bagi setiap individu, apa pun bentuk stimulannya. Karena behaviorisme mengabaikan faktor internal, maka seketika orang diberikan stimulus tertentu maka respon diandaikan akan muncul, dengan tipe-tipe tertentu yang sebenarnya dapat diprediksi. Jika seorang anak memperoleh stimulus yang terus-menerus berupa tontonan (film, games) yang berbau kekerasan maka respon yang kemudian muncul adalah 
meningkatnya perilaku kekerasan anak dan hal ini ternyata telah dibuktikan di banyak kasus. Dalam kasus yang lain dibuktikan juga ternyata bahwa perilaku seksual pranikah di kalangan anak remaja disebabkan karena seringnya mereka menonton video-video porno di berbagai situs yang sangat mudah diakses. Beberapa kondisi tersebut menunjukkan bahwa memang faktor eksternal memiliki pengaruh yang sangat besar dalam menentukan perilaku seseorang. Maka antisipasi yang dapat dilakukan sebenarnya adalah membangun sistem agar faktor eksternal (lingkungan) dapat dipastikan memberikan input atau stimulus yang baik kepada individu. Karena behaviorisme mengabaikan faktor kesadaran maka memastikan stimulus luar sesuai dengan kerangka yang ingin dituju adalah hal yang harus diciptakan. Analoginya mirip dengan model conditioning yang telah dipaparkan oleh para tokoh behavioris. Dengan mekanisme conditioning tersebut maka perilaku yang diinginkan dapat diwujudkan. Sekali lagi perlu diingat bahwa apa yang dipaparkan oleh behavioris ini berpijak dari asumsi diri manusia yang sangat mekanis, dengan mengabaikan faktor kesadaran yang ada pada diri manusia. Oleh karena itu terlepas dari kelemahannya tersebut, sesungguhnya apa yang digagas oleh behaviorisme dalam konteks kekinian cukup relevan. Sehingga pijakan teoritik dari behaviorisme sesungguhnya dapat digunakan sebagai tawaran alternatif bagi penyelesaian persoalan kekinian.

\section{SIMPULAN}

Berdasarkan paparan pada bab di atas maka dapat diambil kesimpulan sebagai berikut:

Munculnya behaviorisme sebagai sebuah mainstream dalam psikologi diawali dengan dasar pemikirannya yang berseberangan dengan model berpikir ala Cartesian. Jika filosofi pada pemikiran ala Cartesian lebih bersifat inside out (dari dalam ke luar) maka pada behaviorisme, faktor luar atau eksternal-lah yang akan mempengaruhi. Pada pemikiran Cartesian dikatakan bahwa apa yang dipersepsi oleh manusia bukanlah karena apa yang ada di 
dunia luar, melainkan hal itu dikarenakan adanya ide, tanda, ataupun representasi lain yang muncul dari dalam diri (cogito). Konsekuensi dari hal ini adalah tubuh hanyalah bersifat mekanis. Bekerjanya tubuh diibaratkan seperti mesin yang semuanya dapat dijelaskan dengan hukum-hukum mekanis. Karena bekerjanya tubuh bersifat mekanis, maka untuk mempelajari kesadaran hal itu dapat dilakukan dengan cara introspeksi. Memahami apa yang terjadi dalam diri melalui pemahaman dan refleksi diri. Metode introspeksi ini kemudian digunakan dalam ranah psikologi (dapat dilihat pada fase awal didirikannya laboratorium psikologi oleh Wilhem Wundt di Leipzig Jerman).

Penggunaan metode introspeksi dalam psikologi ternyata menimbulkan banyak masalah, utamanya adalah terjadinya solipsisme karena dengan metode introspeksi seseorang hanya dapat mengetahui pikirannya sendiri, tidak mungkin bagi dirinya untuk mengetahui pikiran orang lain. Sehingga pengalaman pribadi seseorang akhirnya menjadi satu-satunya fakta yang dapat diterima, karena tidak ada realitas lain selain diri sendiri. Penjelasan ini dipandang sangat tidak memadai, karena tidak dapat disesuaikan dengan penjelasan fisika mekanis maupun biologi evolusioner. Di samping itu juga metode introspeksi dipandang tidak sesuai dengan logika rasionalisme yang mampu menganalisis perilaku manusia secara pasti seiring dengan tuntutan perkembangan keilmuan yang lebih bersifat positivistik.

Berdasarkan berbagai persoalan tersebut di atas maka muncullah behaviorisme sebagai sebuah mainstream dalam psikologi. Adapun asumsi utama yang dibangun oleh behaviorisme psikologis adalah sebagai berikut: fokus studi psikologi adalah pada perilaku dan bukan pada kondisi mental internal, tujuan dari psikologi adalah prediksi perilaku, serta tubuh manusia bersifat mekanis yang secara kualitatif tidak jauh berbeda dengan hewan, hanya bersifat lebih kompleks saja. Sehingga tidak ada perbedaan secara kualitatif (fundamental) antara perilaku manusia dan non-manusia. Mengacu pada yang diteorisasikan oleh Darwin, bahwa manusia berevolusi 
dari spesies yang lebih sederhana, maka perilaku manusia dapat disimpulkan sebagai bentuk perilaku yang lebih kompleks dari spesies-spesies yang lain.

Berdasarkan asumsi yang dibangun tersebut dapat dianalisis beberapa persoalan yang mendasar, antara lain yaitu: pertama, diabaikan atau bahkan ditolaknya kesadaran sebagai bagian yang harus dipertimbangkan dalam perilaku manusia. Kedua, penjelasan yang sangat mekanis ala behavioris hanya mampu menjelaskan perilaku manusia dalam term causa materialis, formalis, dan efficient, namun dengan mengabaikan kausa finalis. Padahal dalam kausa finalis dapat ditemukan penjelasan perilaku yang bersifat intensional. Ketiga, behaviorisme terlalu dogmatis dalam tujuannya untuk memprediksi perilaku. Behaviorisme mengandaikan akan selalu terjadi paralelitas antara stimulus eksternal dengan kondisi mental internal dan respon internal. Padahal dalam kenyataannya banyak perilaku yang sengaja disembunyikan untuk tujuan-tujuan tertentu. Artinya tidak selalu terjadi paralelitas antara kondisi mental internal dengan perilaku yang nampak. Keempat, penjelasan behaviorisme tidak dapat digunakan untuk menjelaskan perkembangan kemampuan kebahasaan pada manusia.

Terlepas dari berbagai kelemahan yang ada dalam psikologi behavioris, namun tetap ada hal yang dapat diambil dan cukup relevan untuk dipertimbangkan dalam konteks perilaku masyarakat di era sekarang, yaitu tentang peran stimulus eksternal dalam era digital. Pada saat sekarang di mana perkembangan teknologi informasi sangat pesat, stimulus eksternal ini menjadi lebih tidak terbendung. Berbagai informasi dari dunia maya tersebut akan menjadi stimulus yang sangat kuat untuk mempengaruhi atau bahkan menentukan perilaku seorang individu. Hukum-hukum pembelajaran dari behaviorisme akan berlaku di sini. Misalnya anak yang sering menyaksikan adegan kekerasan di media maka akan memiliki kecenderungan untuk meniru apa yang dia lihat, atau perilaku seksual di kalangan remaja yang semakin meningkat sebagai akibat dari banyaknya situs yang tidak layak untuk mereka 
lihat namun sudah mereka konsumsi. Artinya proses pembelajaran seperti yang diteorisasikan oleh behaviorisme memang benar adanya. Sehingga jika ingin mengubah situasi tersebut maka stimulusnya yang harus dirubah, atau dikondisikan sedemikian rupa sehingga ada batasan secara sistemik bagi anak-anak misalnya untuk dapat mengakses hal-hal tersebut di atas. Mekanisme inilah yang kemudian dapat diibaratkan sebagai proses conditioning dalam konteks behaviorisme, sehingga perilaku yang nantinya muncul dapat sesuai dengan yang diinginkan (diprediksi).

\section{DAFTAR PUSTAKA}

Darity Jr, William A., (ed), 2008, International of Encyclopedia of The Social Sciences (2nd edition), Mac Millan Social Science Library.

Hocutt, Max, 1996, "Behaviorism as Opposition to Cartesianism" dalam The Philosophy of Psychology, Sage Publication, London.

Jarviss, Matt, 2000, Teori-teori Psikologi, Nusa Media, Bandung.

Mason, Kelby, etc, $\mathrm{tt}$, The Philosophy of Psychology in Routledge Companion to twentieth Century Philosophy, Routledge, London dalam

http://www.rci.rutgers.edu/ stich/Publications/Papers/PHILOS OPHYofPSYCHOLOGY.pdf

O'Donohue, William, and Richard F. Kitchener, 1996, The Philosophy of Psychology, Sage Publications, London.

Trout, J.D., 1991, "The Philosophy of Psychology" dalam The Philosophy of Science, A Bradford Book The MIT Press, Cambridge, Massachusetts, London England.

Rychlak, Joseph F., 1996, "Must Behavior be Mechanistic? Modelling Nonmachines" dalam The Philosophy of Psychology, Sage Publication, London.

Sarwono, Sarlito Wirawan., 2009, Pengantar Psikologi Umum, Raja Grafindo Persada, Jakarta. 
192 Jurnal Filsafat Vol. 27, No. 2, Agustus 2017

Suriasumantri, Jujun S. 1990, Filsafat Ilmu: Sebuah Pengantar Populer, Percetakan Sinar Agape Press, Jakarta.

Suriasumantri, Jujun S., 1986, Ilmu dalam Perspektif Moral, Sosial, dan Politik: Sebuah Dialog tentang Dunia Keilmuan Dewasa ini, Gramedia, Jakarta 